\title{
BELIEVABILITY OF SOCIAL MEDIA POSTS: A STUDY OF ALLEGED FORCEFUL INJECTION OF MONKEY POX VIRUS IN SCHOOL CHILDREN
}

\author{
By \\ Nnaemeka, Obidike Frank Ph.D \\ Department of Mass Communication. \\ Chukwuemeka Odumegwu Ojukwu University \\ frank.nnaemeka@yahoo.com \\ Onunkwor, Ikemefuna Stanley Ph.D \\ Department of Mass Communication \\ Chukwuemeka Odumegwu Ojukwu University \\ onunkworstanley@yahoo.com
}

\begin{abstract}
This study investigated the believability of alarmist social media posts among civil servants in Anambra State with particular reference to the Nigerian Army's "deadly vaccine" episode of October 11, 2017, that caused significant panic in Anambra State. Situated within the framework of Source Credibility Theory, the study adopted the survey research design. The population of the study was civil servants working in the State Secretariat, Awka, from where a sample of 341 was selected. The data collection instrument was questionnaire comprising 21 close ended items. Findings from the study showed among others that: most civil servants in Anambra State were exposed to October 11, 2017, social media posts on the alleged forceful injection of monkeypox virus in school children and that the social media platform; WhatsApp was the primary source of this exposure; most civil servants believed the posts, reacted mainly by bringing their wards back from school and by alerting others of the perceived danger. The study also found that gender, age, education, and length of civil service experience influenced believability and response to the October 11, 2017 social media posts on the alleged forceful injection of monkeypox virus in schoolchildren among civil servants in Anambra State. The study concluded among others that: social media had become essential channel of communication with widespread appeal, and credibility and they exert considerable influence on public opinion formation. It was, among others, recommended that there should be a persistent campaign to educate the people on the risk of indiscriminate reliance on social media for critical information to avert levels of misinformation as experienced in the so-called army "deadly vaccine" episode in Anambra State.
\end{abstract}

Key words: Social Media; Alarmist Post; Believability; Monkey Pox; Vaccine;

\section{INTRODUCTION}

On Wednesday, October 11, 2017, wild news started making the round that officers of the Nigerian Army were going around schools in Anambra State and forcefully injecting school children with a vaccine said to contain monkeypox virus. In other words, the soldiers were alleged to be infecting the children with the virus, and a number of them were said to have died upon receiving the injection (Okachie, 2017; Umahi, 2017). The above 'rumuor' had developed following the internal security exercise codenamed "Operation Egwu Eke II" (Python Dance II) launched by the 82 Division of the Nigerian Army in Southeast. Incidentally, the operation had already been mired in controversy following the notion that it was targeted at suppressing the Igbo separatist group, Indigenous People of Biafra (IPOB) and allegations of human rights abuses leveled against the Army in the course of the 
DOI: http://dx.doi.org/10.47851/naujocommed.v2i1.121

operation. Thus, "Operation Python Dance II" as well as the Nigerian Army executing it was already portrayed in the eyes of many South-Easterners, as an enemy aiming to intimidate and even destroy the people of the zone.

Consequently, when it was alleged that the soldiers as part of "Operation Python Dance II," were injecting school children with a deadly vaccine, the allegation quickly carried considerable persuasive force seriously causing significant tensions in Anambra State and indeed the entire Southeast. Umahi $(2017$, p. 3) captures the mood of the day as follows: There is commotion in the entire Southeast zone as a result of the widespread rumuor, which held that people in army uniform have invaded schools, injecting pupils and students to death with a vaccine linked to monkeypox. The report, which held that some parents were refused to take home their children in Enugu, also had it that students, who were scared of immunization were seen rushing home as the panic over monkeypox 'vaccine' spread in Southeast yesterday. The development that came to light in the last 48 hours has created confusion and anxiety, leading to stampede in States within the zone as parents dashed to various nursery and primary schools to evacuate their children and wards.

In Anambra State, many parents rushed to pick their children from school while those of the pupils and students old enough to find their way home departed schools independently. The panic was serious that within a period of time, activities in most schools in the state were halted and became deserted (Okachie, 2017; Umahi, 2017). However, subsequent official reports showed that the reported deadly vaccine was a mere rumuor which emanated from a school head in Ekwusigo Local Government Area of Anambra State who, on seeing the soldiers who came to the school on a medical outreach, raised the alarm that the soldiers had come to infect the pupils (Okachie, 2017). Various social media platforms amplified and widely spread the rumuor (Okachie, 2017; Umahi, 2017) as people posted and shared the alarming message.

In a statement, the Army said: The attention of the 82 Division Nigerian Army (NA) has been drawn to a silly and mischievous publication on social media, which alleged that the ongoing free medical services holding in some communities in the Southeastern Region of Nigeria is to depopulate the region through the so-called "monkeypox vaccination" (Umahi, 2017, p.3).

While the deadly vaccine episode might not have originated from social media, it is possible that social media platforms played a significant role in spreading it. It is also possible that social media mediation gave the message the widest publication. It is noted that earlier in 2014, in the wake of the Ebola virus epidemic in Nigeria and parts of West Africa, Nigerians had woken up one day to the following message spread mainly through phone calls and social media. The message wanted people to a considerable quantity of mix salt in a cup of water and drink it. It also held that people should mix salt in a bucket of water and bath with it to protect them against contracting Ebola virus. According to Obukoadata \& Abuah (2014), it was a big surprise, the speed at which a large segment of the society caught the message and acted on the prescribed antidote. The study therefore held that it was an indication of the power of social media, facilitated by the unregulated nature of the internet, which renders it susceptible to inaccuracies and mischief (Obukoadata \& Abuah, 2014). Against this backdrop, this study investigated the believability of alarmist social media posts among civil servants in Anambra State with particular reference to the army "deadly vaccine" episode of October 11, 2017. 


\section{STATEMENT OF THE PROBLEM}

Social media platforms, given their ubiquitous and interactive nature, have now become a veritable source of information and interaction amongst Nigerians and beyond (Okoye, 2011; Nwosu, 2012). However, these features have portrayed social media as potentially harmful in spreading misleading information indiscriminately consumed by ignorant or merely malevolent users (Akindehin \& Akindehin, 2011; Adaja \& Ayodele, 2013). Consequently, social media users are always confronted with the danger of falling prey to misinformation (Okoye, 2011). Civil servants in Anambra State may have believed social media posts on the army "deadly vaccine" as held by media dependency theory and falling prey to the misinformation represented therein.

Nevertheless, the question arises; why did the civil servants believe the 'deadly vaccine' news? Why did they react so clearly by evacuating their wards from schools and persuading others to do the same without seeking other sources despite their level of education, social status, and other indices? Why was it 'so easy' for these civil servants to believe the alarming news from social media?

\section{OBJECTIVES OF THE STUDY}

This study intended to investigate the believability of alarmist social media posts among civil servants in Anambra State with particular reference to the army "deadly vaccine" episode of October 11, 2017. In more precise terms, the study pursued the following objectives:

1. To determine the proportion of civil servants in Anambra State exposed to social media posts on the alleged forceful injection of monkeypox virus in school children.

2. To determine the proportion of the civil servants that acted in line with social media posts made on the monkeypox virus in school children.

3. To ascertain the demographic variables that influenced the believability of the social media posts on the alleged forceful injection of monkeypox virus in school children.

4. To examine the demographic variables that influenced response to the social media posts made on the alleged forceful injection of monkey pox virus in school children.

\section{LITERATURE REVIEW}

\section{i. Empirical review}

Nababa (2016) investigated the credibility of information on social networking sites due to a prank on the networks to prevent the spread of the Ebola virus in Nigeria. The study looked at how active users of the networks spread false information about a salt-and-warm-water solution as prevention for Ebola. This information according to the study later led to the loss of lives and many other people hospitalized due to excessive consumption of salt due to the misinformation. The study adopted a structured questionnaire as method of data collection and then surveyed 114 active users of the social networks on the credibility of the salt-andwarm-water solution on the networks. The findings revealed that though majority of the respondents learned about the deadly hoax on the social networks, it was not the credibility of information on the networks that led some of them to use the salt solution. The majority of the respondents who used the salt solution indicated that interpersonal relationships were their primary motivators that made them take the risky actions. 
Adeyanju (2015) carried out a comparative examination of the news credibility of social media, television, and newspapers. The study utilized both focus group discussion and the survey method. The study was anchored on Source Effects Model as the theoretical framework. Findings revealed among others that respondents' level of education and knowledge of the internet influenced the selection and believability of news; that those who placed news contents from television and newspaper as higher on the credibility scale than social media did so because news items from the newspapers and on television are produced by well-trained personnel. There are institutionalized ways of filtering (gate keeping process) news stories to ensure their accuracy and objectivity.

Ugwuanyi (2017) investigated the influence circulation of fake news has on Nigerians about the perception of online newspapers. The study adopted Uses and Gratifications, and the Selectivity Factors theories as theoretical framework. Employing the survey research design, the researcher drew the sample size from the Enugu metropolis. Findings indicated that while there is high prevalence of fake news in Nigeria, popular online newspapers do not play numerous roles in spreading fake news; that most Nigerians see reports on popular online news platforms as credible; and that there is a difference between the information on online newspapers and those circulated through social media.

\section{ii. Conceptual Clarifications: Social Media}

Social media are the various internet applications that build on Web 2.0, which allow for the creation and exchange of user-generated content online. Social media allow for interactivity among users. Social media include text, audio, video, images, podcasts, and other multimedia communications. Bryer \& Zavattaro (2011) aver that: Social media include web-based and mobile technologies used to turn communication into interactive dialogue. Social media take on many different forms, including magazines, Internet forums, weblogs, social blogs, microblogging, wikis, podcasts, photographs or pictures, video, rating, and social bookmarking, by applying a set of theories in media research (social presence, media richness) and social processes (self-presentation, self disclosure).

Social media have permeated today's world such that their penetration has risen monumentally in the developed world, with developing countries like Nigeria fast becoming integrated into the new trend. A report by Nielson, Bryer \& Zavattaro (2011), states that in the U.S. alone, total minutes spent on social networking sites have increased to 83 percent year-over-year, with similar increases experienced in other parts of the developed world and of course with the Third World making steady, significant progress.

Social media have become a part and parcel of people's way of communicating, staying in touch, keeping on top of new happenings and connecting with the world around them (Okoye, 2011; Nwosu, 2012). With their ubiquitous and interactive nature, social media have become a veritable source of disseminating information and interaction amongst Nigerians and beyond (Nwosu, 2012). As at June 30, 2017, Nigeria recorded over 19.5million social media access, with Facebook claiming 16,000,000 users amounting to $89.05 \%$ of the social media penetration in Nigeria (Internet World Stats, 2017). Commenting on the growing accessibility and influence of social media in Nigeria, Akinlade (2017) states that social media platforms occupy a lofty height among the population of Nigeria and have indeed, exert formidable influence as a shaper of public opinion. 


\section{iii. The Concept of Credibility}

Credibility refers to the state of being trustable and believable. In the communication context, implies the level of trust and persuasion a communicator, a channel, and a message could command in a given target audience (Alawode \& Adesanya, 2016). Kaufman, Stasson, and Hart (1999) emphasized that the credibility of the news sources is vital to audience members. It is so because it plays a signi*cant role in the way the audience interprets and understands information. The study of media credibility can be viewed from two approaches, which include medium credibility, and source credibility. The approach from source credibility is used to investigate the expertise and trustworthiness of the person who initiates the message or communication. On the other hand, the medium credibility is used to measure the credibility of media channels the communicator uses in disseminating information (Graziano and McGrath, 1986; Metzger, 2003).

Cross comparison of media (channel) credibility has been a recurring research theme for mass communication scholars and journalists, mainly since Roper polls in the early 1960s showed that audiences evaluated television as a more credible news channel than newspapers (Gaziano \& McGrath, 1986). The credibility of television, newspapers, radio, and magazines has been measured and compared: Television has frequently been the most credible medium, but overall credit ratings of all media have declined over time (Finberg \& Stone, 2002). Reliance is an attitudinal value towards media on which audiences depend for gaining information (Johnson \& Kaye, 2000). Reliance is important to the extent the media in+uence the audience (Chinedu-Okeke \& Obi, 2016). If news audiences perceive the internet to be highly credible as a news medium, they become highly dependent on that medium. However, credibility perception has shown a weak association with newspapers and television use (Rimmer \& Weaver, 1987; Wanta \& Hu, 1994). These findings from past studies, while suggestive, have not have been sufficient to establish the relationship between reliance and media credibility for all media.

Another aspect of channel credibility relates to the ownership of and editorial leaning of a media house in question. For instance, a media house known to have links with the government may lose credibility in the eyes of specific segments of the audience as a source of news on a controversial matter to which government is a party. Thus, Emetumah (2016) notes that most Nigerians have trust on news concerning the government more if it is aired on a private news channel than when it is disseminated by a government-owned station. Graziano and McGrath (1986), states that credibility is anchored on believability, trust, and perceived reliability. According to Chinedu-Okeke and Obi (2016), being these three dimensions of objectivity are mostly interwoven, with each determining and are determined by the other.

\section{iv. Social Media, Misinformation and Credibility Concern}

Over the years, the issue of concerns and skepticism have been raised on the credibility of social media and online news content because of the questions of professionalism, anonymity of sender location, etc, (Hilingoss and Rieh, 2008; Kiousis, 2001; Chukwunwike, 2017). Abdulla, Garrison, Salwen, Driscoll, and Casey (2002, p. 18) state that: The proliferation of various online news platforms to the list of sources for the dissemination of information available to the public has led to concerns about its credibility. It has also tasks the perception of the public concerning its use as a news source vis-à-vis established and more traditional 
DOI: http://dx.doi.org/10.47851/naujocommed.v2i1.121

news sources. It follows therefore that as access and availability of online news grow, the concern for the quality of the information found online will also increase.

Another factor in discussion of the credibility of news on social media is whether the definition of what is news on mainstream media is the same as the meaning of news on social media. Also, does the information pass through the filtering (gatekeeping) process that the mainstream media is known for, and if it does, what is the means of attributing the source of news to a particular person? Chukwunweike (2017) answers this question in the negative. He affirms that the social media do not admit of the existence of any gate and therefore essentially gateless. For that reason, anything can go in.

Internet credibility is also a important concern being that seeking information is one of the primary purposes of making use the internet. Users of online platforms have easy access to avalanche of sources and therefore run the risk of receiving false information. There is less control and gate-keeping on the Web than for print publications. No government, whether authoritarian or democratic institutions can vet all the information on the Internet due to its nature. Virtually, everyone could publish on the internet (Gilster, 1997). However, people who are less critical and uninformed are more likely to accept what is not truth as a truth (Hernon, 1995). Infordemic on the Web becomes the order of the day because there is too much information. The more information is put on the internet, the more chance of discovering misinformation decreases. In addition to that, most people neither have time to verify its accuracy nor go back to the same site because the browser may fail to find it again (Calvert, 2001). Individual education is the most plausible way to avoid getting inaccurate information.

\section{THEORETICAL FRAMEWORK}

This study was anchored on source credibility theory. The theory describes the positive disposition of a communicator that affects a receiver's acceptance of a message. Studies on this theory began in the 20th century and gained popularity during World War II when the U.S. government used propaganda to influence public opinion in support of the efforts to win the war (O'Mahony \& Meenaghan, 1988; Erdogan, 1999). Source credibility theory explains how communication's persuasiveness is affected by the perceived credibility of the communication source. The credibility of any information, no matter the format used in the dissemination is significantly influenced by the understanding that the source of that information is credible (O'Mahony \& Meenaghan, 1988). The theory presupposes that the disposition of a source of a particular information may have a positive effect on the audience's reception to the conveyed message" (Erdogan 1999, p.297). The theory further explains that the acceptance level and favorable impact of a message depends on the how the audience perceives the abilities, honesty and knowledge of the source (O'Mahony \& Meenaghan, 1988; Erdogan, 1999).

According to Goldsmith, Lafferty and Newell (2000), source credibility describes the extent to which the source is perceived as possessing the capacity, ability, and know-how relevant to the communication topic and is embedded with the trust to give an objective opinion on the subjectmatter. Hovland and Weiss (1951) reaffirmed the above position that credibility of a communicator reflects the public perception of the communicator's fairness and factualness. 
DOI: http://dx.doi.org/10.47851/naujocommed.v2i1.121

There are several dimensions of credibility that affect how an audience will perceive the speaker. These include: competence, extraversion, composure, character, and sociability. These dimensions have been explained by Goldsmith, Lafferty, and Newell (2000) as follows: Competence: The measurement of competence is based on seven values. These values are: qualification, expertise, reliability, believability, openness (i.e., intellectual vs. narrow), value, and currency (i.e., informed vs. uninformed).

Character: The measurement of character has four values. These are kindness, sympathy, selflessness (i.e., unselfish vs. selfish), and virtue. Sociability: The measurement of sociability has three values. These are friendliness, cheer, and temperament (i.e., goodnatured vs. irritable). Character and sociability could be joined by some researchers. In that case, researchers will employ the seven values under one "Character-Sociability" measurement.

Composure: Four seemingly synonymous values are assigned to the measurement of composure. These are excitability (composed vs. excitable), calmness (calm vs. anxious), tension (relaxed vs. tense), and poise (poised vs. nervous).

Extroversion: Like composure, extroversion is composed of four seemingly synonymous values. These are aggressiveness, boldness, talkativeness (i.e., talkative vs. silent), and voice (i.e., verbal vs. quiet).

The Army "deadly vaccine" episode of October 11, 2017, may be seen from the point of the source credibility theory. Members of the public, who may have been exposed to the message via social media may have also act upon it and may have seen social media as a credible source. If they saw social media as credible sources of information, they would be more likely to find the message believable. When the reverse is the case, they would likely not believe it.

\section{METHODOLOGY}

The survey research design was used for this study. A sample survey allows a researcher to study a part (sample) of a given population and then generalize the result to the entire civil servants.

\section{Area of Study}

The area of study was Anambra State, South-East Nigeria. It comprises 21 local government areas made up of mostly rural towns. The State hosts some cities, which include Awka (the State capital), Ekwulobia, Nnewi, Ihiala, and Onitsha.

\section{Population of Study}

The study population was the civil servants in Anambra State who work in the State Secretariat, Awka. The population of these civil servants is 3,014, according to the data supplied by the Office of the Head of Service of the State. This population includes workers of all cadres, beginning from the Level 01 to 16

\section{Sample Size and Sampling Procedure}

Arnold (2010) describes sampling as "the process of selecting units (e.g. people, organizations) from a population of interests so that by studying the sample we may fairly generalize our results back to the population from which they were chosen" (p.2). 
Volume 2 Number 1 Jan-Mar Issue

DOI: http://dx.doi.org/10.47851/naujocommed.v2i1.121

To determine the sample size of the study, the researcher relied on sample sizes for various population ranges as worked out by Meyer (1973). This is as represented in Table 1 below.

Table 1 Populations and Sample Sizes as Determined by Meyer (1973)

\begin{tabular}{|l|l|l|}
\hline S/N & Population Size & Sample Size \\
\hline 1. & Infinity & 384 \\
\hline 2. & 500,000 & 384 \\
\hline 3. & 100,000 & 383 \\
\hline 4. & 50,000 & 381 \\
\hline 5. & 10,000 & 370 \\
\hline 6. & 5,000 & 357 \\
\hline 7. & 3,000 & 341 \\
\hline 8. & 2,000 & 322 \\
\hline 9 & 1,000 & 278 \\
\hline
\end{tabular}

Thus, given that the population of study was 3, 222 (and was still below 5,000) the researcher settled for 341 as the study sample.

The sample procedure was the cluster technique. Since the civil servants were grouped in ministries and departments, the researcher adopted these ministries and departments as clusters.

Then, from the clusters, a given number of respondents were randomly chosen. The number selected from each cluster was determined using the following formula:

$\mathrm{X}=\frac{\mathrm{n}}{\mathrm{N}} \quad \mathrm{X} \quad \frac{\mathrm{S}}{1}$

Where $\mathrm{X}=$ number selected from each ministry/department

$\mathrm{n}=$ population of each ministry/dept

$\mathrm{N}=$ Collective population of the entire ministries/departments

$\mathrm{S}=$ Sample size

Table 2 Sampling Frame

\begin{tabular}{|l|l|l|}
\hline S/N & Ministry/Department & $\begin{array}{l}\text { No. of } \\
\text { personnel }\end{array}$ \\
\hline 1. & Ministry of Trade, Commerce, Market and Wealth Creation & 267 \\
\hline 2. & Ministry of Economic Planning, Budget \& Development Partners & 170 \\
\hline 3. & $\begin{array}{l}\text { Ministry of Finance, Industry, Innovations \& Dev. Financial } \\
\text { Institutions }\end{array}$ & 292 \\
\hline 4. & Head of Service and Permanent Secretaries & 23 \\
\hline 5. & Ministry of Housing \& Urban Renewal & 99 \\
\hline 6. & Ministry of Information \& Culture & 333 \\
\hline 7. & Ministry of Environment, Beautification and Ecology & 100 \\
\hline 8. & Ministry of Health & 646 \\
\hline 9 & Ministry of Justice & 199 \\
\hline 10. & Ministry of Transport & 41 \\
\hline
\end{tabular}


DOI: http://dx.doi.org/10.47851/naujocommed.v2i1.121

\begin{tabular}{|l|l|l|}
\hline 11. & Office of the Head of Service & 757 \\
\hline 12. & Ministry of Mineral Resources, Science \& Technology & 87 \\
\hline 13 & Ministry of Education & 295 \\
\hline & TOTAL & $\mathbf{3 , 2 2 2}$ \\
\hline
\end{tabular}

Source: Office of the Head of Service, Anambra State(2017).

Thus, the number of respondents selected from each ministry or department is as follows: Ministry of Trade, Commerce, Market and Wealth Creation (30); Ministry of Economic Planning, Budget \& Development Partners (19); Ministry of Finance, Industry, Innovations \& Dev. Financial Institutions (33); Head of Service and Permanent Secretaries (3); Ministry of Housing \& Urban Renewal (11); Ministry of Information \& Culture (38); Ministry of Environment, Beautification and Ecology (11); Ministry of Health (73); Ministry of Justice (23); Ministry of Transport (5); Office of the Head of Service (85); Ministry of Mineral Resources, Science \& Technology (10). This gave the required total of 341 respondents.

\section{Instrument of Data Collection}

The data collection instrument was questionnaire. The questionnaire comprised entirely close-ended questions -21 in all. The first segment of the questionnaire contained questions on the respondents' demographics; the second segment was on their access to social media; the third was on their exposure to the October 112017 army "deadly vaccine" episode; the fourth was on their believability of the report of the episode; while the fifth segment was on their reaction to the report.

\section{Pre-test of Instrument}

To test the validity and reliability of this instrument, the researcher conducted a pilot study using 20 respondents randomly selected from his population.

The instrument was administered to the respondents who filled and returned them. Analysis of their answers convinced the researcher of his instrument's validity.

To further confirm its reliability (consistency), the researcher re-administered the same instrument to the same 20 respondents after two weeks of the first exercise.

Analysis of their answers this time showed that there was no significant difference between them and the answers they supplied in the first exercise.

This convinced the researcher of his instrument's reliability.

\section{Method of Data Analysis}

Method of data analysis was quantitative. Answers extracted via the questionnaire were recorded as numeral data. The frequency of each answer was found and the percentage computed accordingly.

Statistical tables were used to present these data while further illustrations were made using charts. The research questions were answered by observing and interpreting the statistical relationships between relevant variables. 
NNAMDI AZIKIWE UNIVERSITY JOU

Journal OF COMMUNICATION HND MEDL STUDIES

Volume 2 Number 1 Jan-Mar Issue

DOI: http://dx.doi.org/10.47851/naujocommed.v2i1.121

ISSN:2756-486X (Online)

DATA PRESENTATION AND ANALYSIS

Response Rate

Table 3 Response Rate

\begin{tabular}{|l|l|l|}
\hline & Frequency & Percentage \\
\hline No. Recovered & 332 & $97.4 \%$ \\
\hline No. Not Recovered & 9 & $2.6 \%$ \\
\hline Total & $\mathbf{3 4 1}$ & $\mathbf{1 0 0 \%}$ \\
\hline
\end{tabular}

Table 3 shows that of the total of 341 questionnaire copies distributed, 332 representing 97.4\% were recovered as against 9 representing $2.6 \%$ that were not. Thus, $97.4 \%$ response rate was recorded as against $2.6 \%$ casualty rate.

\section{Demographic Data}

Data were collected for five demographic variables of gender, age, marital status, highest educational qualification and length of civil service experience. The results are as presented in Figures 1 to 5 below.

\section{Figure 1 Respondents' Gender}

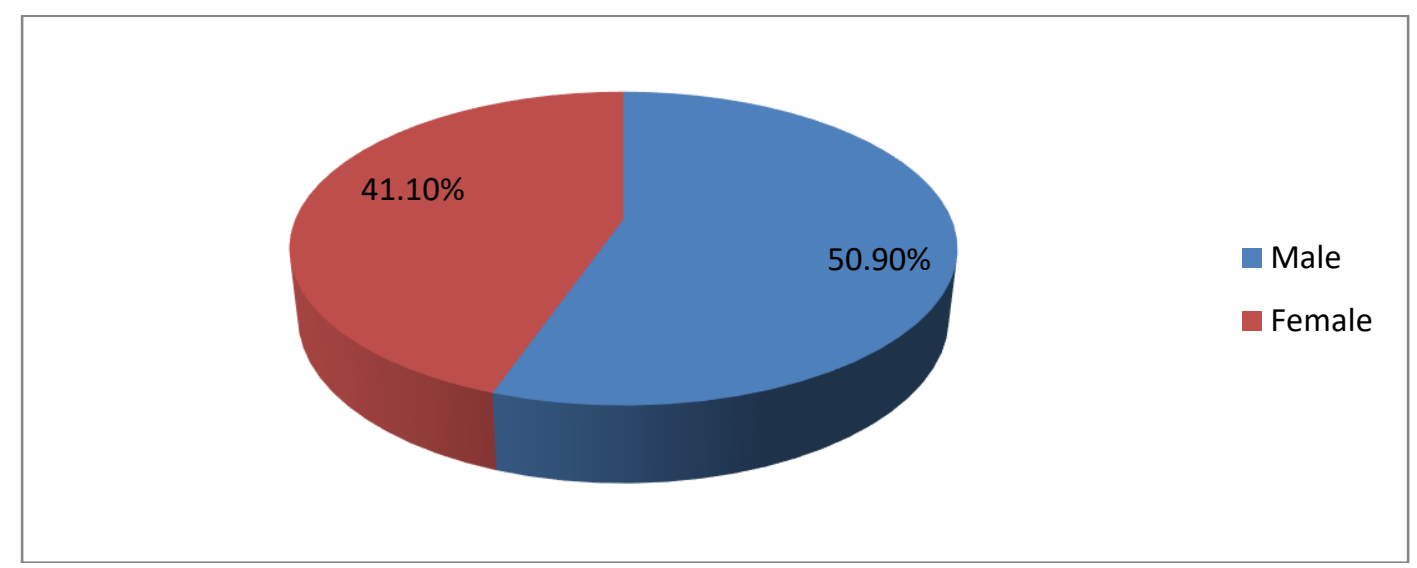

Figure 1 shows that $50.9 \%$ of the respondents are male as against $41.1 \%$ that are female. Thus, there was $9.8 \%$ difference between the number of male and female respondents.

Figure 2 Respondents' Age

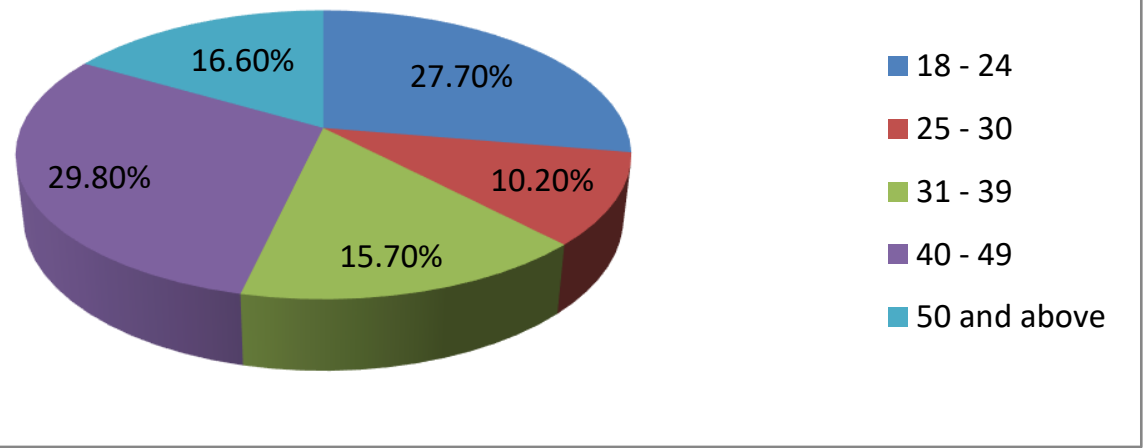


Volume 2 Number 1 Jan-Mar Issue

DOI: http://dx.doi.org/10.47851/naujocommed.v2i1.121

Figure 2 shows that $27.7 \%$ of the respondents were $18-24$ years; $10.2 \%$ were $25-30$ years; $15.7 \%$ were 31 - 39 years; $29.8 \%$ were 40 - 49 years; while $16.6 \%$ were 50 and above. Thus, the modal age bracket was $40-49$ years while 50 and above had the least frequency.

\section{Figure 3 Respondents' Marital Status}

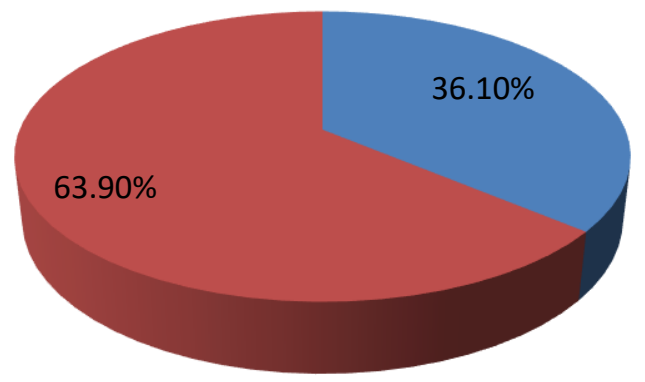

Single

Married

Figure 3 shows that while $36.1 \%$ of the respondents were single, $63.9 \%$ were married. This leaves $27.8 \%$ difference between the number of single and married respondents.

Figure 4 Respondents' Highest Educational Qualification

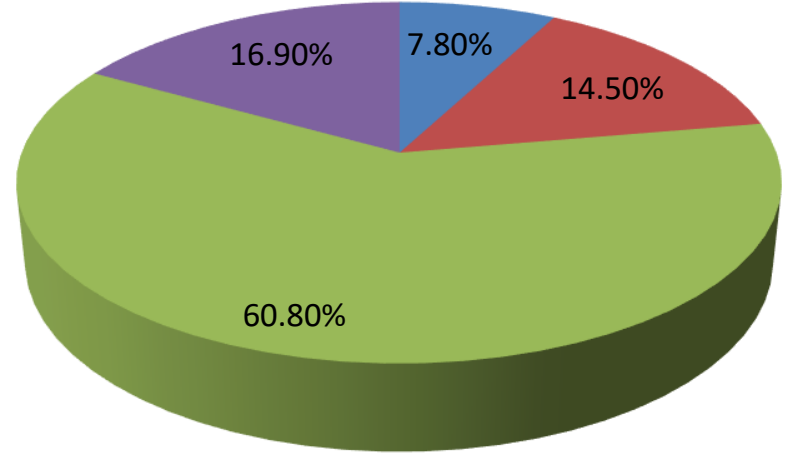

- SSCE/Equivalent

OND/NCE

First degree/HND

- Postgraduate qualifications

Figure 4 shows that $7.8 \%$ of the respondents had SSCE/equivalent, $14.5 \%$ had OND/NCE, $60.8 \%$ had first degree/HND, while $16.9 \%$ had postgraduate qualifications. Thus, first degree/HND had the highest frequency whereas SSCE/equivalent had the lowest.

Figure 5 Respondents' Length of Civil Service Experience 


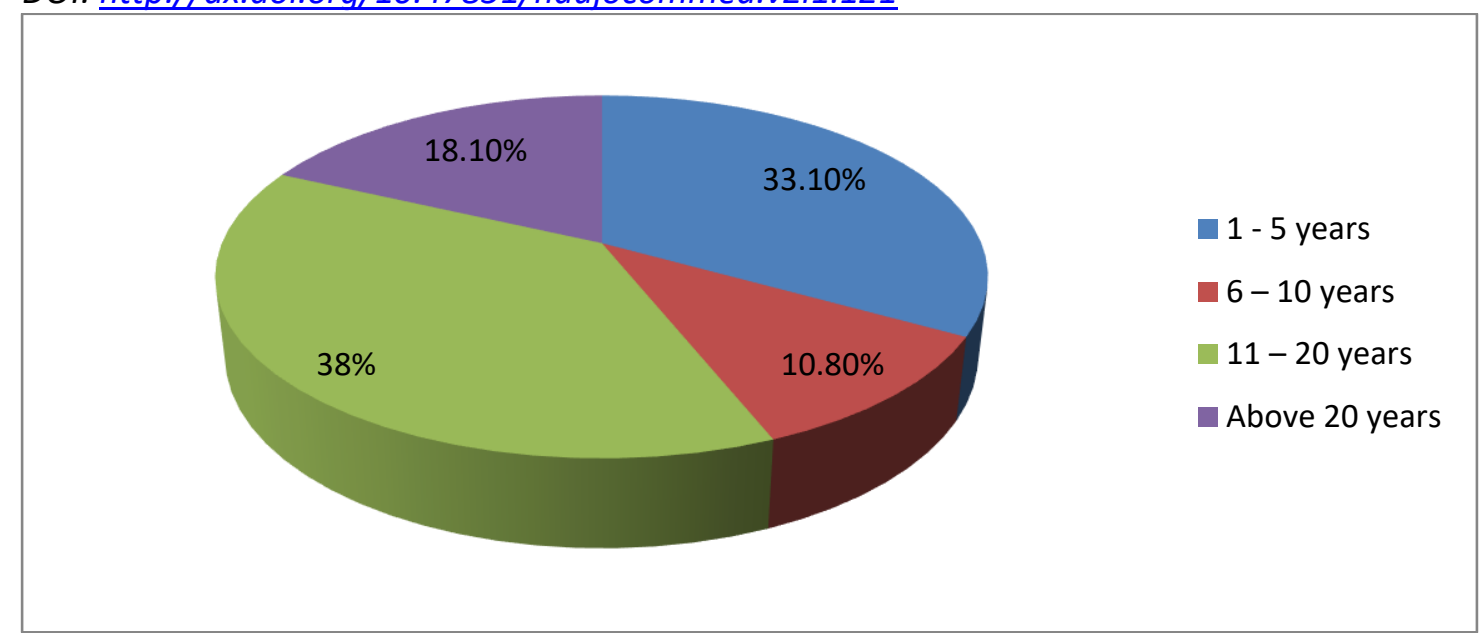

Figure 5 shows that $33.1 \%$ of the respondents had been in service for 1 to 5 years, $10.8 \%$ for $6-10$ years, $38 \%$ for $11-20$ years, while $18.1 \%$ had been there for above 20 years. Thus, 11 -20 years had the highest frequency while $6-10$ years came out with the lowest.

\section{Social Media Access and Uses}

Data were collected on the respondents' social media access and use pattern. These data were in respect to access, platform of access and regularity of access. Data collected in this respect are as presented in Tables 4 to 6 below.

Table 4 Respondents' Access to Social Media

\begin{tabular}{|l|l|l|}
\hline & Frequency & Percent \\
\hline Yes & 310 & 93.4 \\
No & 22 & 6.6 \\
Total & 332 & 100.0 \\
\hline
\end{tabular}

Table 4 shows that $93.4 \%$ of the respondents had access to social media as against $6.6 \%$ that did not. Thus, most of the respondents had access to social media, with $86.8 \%$ difference between the number that had access and the number that lacked it.

This increases the likelihood that majority of the respondents would be exposed to information disseminated through social media such as the post on the army "deadly vaccine".

Table 5 Social Media Platforms Accessible to Respondents

\begin{tabular}{|l|l|l|l|l|l|l|}
\hline & Facebook & WhatsApp & Instagram & Twitter & YouTube & Others \\
\hline Yes & $83.7 \%$ & $78.9 \%$ & $38.6 \%$ & $16.3 \%$ & $34.9 \%$ & $19.3 \%$ \\
& $\mathrm{~N}=278$ & $\mathrm{~N}=262$ & $\mathrm{~N}=128$ & $\mathrm{~N}=54$ & $\mathrm{~N}=116$ & $\mathrm{~N}=64$ \\
\hline No & $16.3 \%$ & $21.1 \%$ & $61.4 \%$ & $83.7 \%$ & $65.1 \%$ & $80.7 \%$ \\
& $\mathrm{~N}=54$ & $\mathrm{~N}=70$ & $\mathrm{~N}=204$ & $\mathrm{~N}=278$ & $\mathrm{~N}=216$ & $\mathrm{~N}=268$ \\
\hline Total & $\mathbf{1 0 0 \%}$ & $\mathbf{1 0 0 \%}$ & $\mathbf{1 0 0 \%}$ & $\mathbf{1 0 0 \%}$ & $\mathbf{1 0 0 \%}$ & $\mathbf{1 0 0 \%}$ \\
& $\mathbf{N}=\mathbf{3 3 2}$ & $\mathbf{N}=\mathbf{3 3 2}$ & $\mathbf{N}=\mathbf{3 3 2}$ & $\mathbf{N}=\mathbf{3 3 2}$ & $\mathbf{N}=\mathbf{3 3 2}$ & $\mathbf{N}=\mathbf{3 3 2}$ \\
\hline
\end{tabular}


Volume 2 Number 1 Jan-Mar Issue

DOI: $\underline{\text { http://dx.doi.org/10.47851/naujocommed.v2i1.121 }}$

Table 5 shows that $83.7 \%$ as against $16.3 \%$ of the respondents had access to Facebook, $78.9 \%$ had access to WhatsApp as against $21.1 \%$. However, while $38.6 \%$ had access to Instagram, $61.4 \%$ did not. In the same vein, only $16.3 \%$ used Twitter as against $83.7 \%$ that did not. Then, $34.9 \%$ had access to YouTube while $65.1 \%$ did not. However, $19.3 \%$ had access to other social media platforms (unspecified) as against $80.7 \% 5$ that did not. Thus, Facebook and WhatsApp were the most accessed social media platforms among the respondents while Twitter was the least.

Table 6 Respondents' Frequency of Access to Social Media

\begin{tabular}{|l|l|l|}
\hline \multicolumn{1}{|l|}{} & Frequency & Percent \\
\hline Always & 168 & 50.6 \\
Sometimes & 110 & 33.1 \\
Rarely & 32 & 9.6 \\
No Access & 22 & 6.6 \\
Total & $\mathbf{3 3 2}$ & $\mathbf{1 0 0 . 0}$ \\
\hline
\end{tabular}

Table 6 shows that $50.6 \%$ of the respondents had access to social media always, $33.1 \%$ had access sometimes, $9.6 \%$ had access to it rarely while $6.6 \%$ had no access at all. In other words, slightly more than half of them had to social media access always. Cumulatively, $83.7 \%$ had access to it either always or sometimes.

\section{Exposure to Army "Deadly Vaccine" Report}

Data were collected in regard to the respondents' exposure to the October 112017 report on Army "deadly vaccine" and the role of social media in this exposure. Data collected in this respect are as presented in Tables 7 to 10 below.

Table 7 Respondents' Exposure to the Army "Deadly Vaccine" Report

\begin{tabular}{|l|l|l|}
\hline & Frequency & Percent \\
\hline Yes & 332 & 100.0 \\
\hline No & 0 & 0.0 \\
\hline Total & $\mathbf{3 3 2}$ & $\mathbf{1 0 0 . 0}$ \\
\hline
\end{tabular}

Table 7 shows that all the respondents were exposed to the October 112017 report on Army "deadly vaccine". Thus, there was $100 \%$ exposure to the report, meaning that each of the respondents must have in one way or the other read or heard about the report.

Table 8 Respondents' Exposure to the Army "Deadly Vaccine" Report Via Social Media

\begin{tabular}{|l|l|l|}
\hline & Frequency & Percent \\
\hline Yes & 284 & 85.5 \\
No & 48 & 14.5 \\
Total & $\mathbf{3 3 2}$ & $\mathbf{1 0 0 . 0}$ \\
\hline
\end{tabular}

Table 8 shows that $85.5 \%$ of the respondents were exposed to the Army "deadly vaccine" report via the social media, while $14.5 \%$ were not. In other words, majority of the respondents got to read the report on social platforms with $71 \%$ difference between the number that were so exposed the number that were not. 
Volume 2 Number 1 Jan-Mar Issue

DOI: $\underline{\text { http://dx.doi.org/10.47851/naujocommed.v2i1.121 }}$

Table 9 Social Media Platforms Via Which Respondents Received the Report of the Army "Deadly Vaccine"

\begin{tabular}{|l|l|l|}
\hline & Frequency & Percent \\
\hline Facebook & 56 & 16.9 \\
WhatsApp & 218 & 65.7 \\
Others & 10 & 3.0 \\
No Answer & 48 & 14.5 \\
Total & $\mathbf{3 3 2}$ & $\mathbf{1 0 0 . 0}$ \\
\hline
\end{tabular}

Table 9 shows that $16.9 \%$ of the respondents were exposed to the Army "deadly vaccine" report via Facebook, 65.7\% via WhatsApp, 3\% via other platforms, while $14.5 \%$ gave no answer. Thus, majority were exposed to the report through WhatsApp.

Table 10 Social Media Platforms as First Source of Respondents' Exposure to the Army "Deadly Vaccine" Report

\begin{tabular}{|l|l|l|}
\hline & Frequency & Percent \\
\hline Yes & 246 & 74.1 \\
No & 86 & 25.9 \\
Total & $\mathbf{3 3 2}$ & $\mathbf{1 0 0 . 0}$ \\
\hline
\end{tabular}

Table 10 indicates that for $74.1 \%$ of the respondents, social media was the first source of exposure to the Army "deadly vaccine" report, while it was not for $25.9 \%$. In other words, there was $48.2 \%$ difference between the number of respondents that were first exposed to the report via social media platforms and the number that were not.

\section{Believability of Army "Deadly Vaccine" Report}

Data were sought on the proportion of the respondents that believed the Army "deadly vaccine" report, the extent of the belief, the point at which this belief occurred and other matters related to it. The computed data are as presented in Tables 11 to 17.

Table 11 Respondents' Belief of the Army "Deadly Vaccine" Report

\begin{tabular}{|l|l|l|}
\hline & Frequency & Percent \\
\hline I completely believed it & 122 & 36.7 \\
I believed it with reservations & 142 & 42.8 \\
I disbelieved it entirely & 24 & 7.2 \\
No Answer & 44 & 13.3 \\
Total & $\mathbf{3 3 2}$ & $\mathbf{1 0 0 . 0}$ \\
\hline
\end{tabular}

Table 11 shows that $36.7 \%$ of the respondents completely believed the "deadly vaccine" report, $42.8 \%$ believed it with reservations, $7.2 \%$ disbelieved it entirely, while $13.3 \%$ gave no answer. Hence, $79.5 \%$ believed the report - either completely or with some reservations.

Table 12 Respondents' Suspicion of Veracity of the "Deadly Vaccine" Report Due to its Social Media Source 
Volume 2 Number 1 Jan-Mar Issue

DOI: http://dx.doi.org/10.47851/naujocommed.v2i1.121

\begin{tabular}{|l|l|l|}
\hline & Frequency & Percent \\
\hline To a large extent & 0 & 0.0 \\
To some extent & 108 & 32.5 \\
To a little extent & 34 & 10.2 \\
Never & 136 & 41.0 \\
No Answer & 54 & 16.3 \\
Total & $\mathbf{3 3 2}$ & $\mathbf{1 0 0 . 0}$ \\
\hline
\end{tabular}

Table 12 shows that none of the respondents to a large extent suspected the veracity of the "deadly vaccine" report due to its social media source, $32.5 \%$ suspected to some extent, $10.2 \%$ suspected to a little extent, $41 \%$ never suspected, while $16.3 \%$ gave no answer. Thus, an appreciable number never suspected the veracity of the report.

Table 13 Respondents' Feeling of Need to Confirm the "Deadly Vaccine" Report From Non-Social Media Source(s)

\begin{tabular}{|l|l|l|}
\hline & Frequency & Percent \\
\hline Yes & 102 & 30.7 \\
No & 156 & 47.0 \\
No Answer & 74 & 22.3 \\
Total & $\mathbf{3 3 2}$ & $\mathbf{1 0 0 . 0}$ \\
\hline
\end{tabular}

Table 13 shows that $30.7 \%$ of the respondents feel the need to confirm the "deadly vaccine" report from non-social media source, $47 \%$ did not, while $22.3 \%$ gave no answer. Thus, close to half of the respondents did not consider it necessary to confirm the report from a source different from the social media.

Table 14 Respondents' First Source of Exposure to the Army "Deadly Vaccine" Report (For Respondents that Did Not Get the Report First From Social Media)

\begin{tabular}{|l|l|l|}
\hline & Frequency & Percent \\
\hline My children's school authorities & 26 & 30.2 \\
My colleagues & 35 & 40.7 \\
My relatives/friends & 15 & 17.4 \\
My neighbours & 8 & 9.4 \\
Others & 2 & 2.3 \\
Total & $\mathbf{8 6}$ & $\mathbf{1 0 0 . 0}$ \\
\hline
\end{tabular}

Table 14 shows that among the respondents who did not get the report of the army "deadly vaccine" first from social media, 30.2\% got it first from their children's school authorities, $40.7 \%$ got it from their colleagues, $17.4 \%$ from their relatives/friends, $9.4 \%$ from their neighbours, while $2.3 \%$ got it from other sources. Thus, colleagues and school authorities featured most prominently as the first sources of the report for those respondents that did not get it first from social media sources. 
DOI: http://dx.doi.org/10.47851/naujocommed.v2i1.121

Table 15 Respondents' Eventual Social Media Exposure to the Army "Deadly Vaccine" Report (For Respondents that Did Not Get the Report First From Social Media)

\begin{tabular}{|l|l|l|}
\hline & Frequency & Percent \\
\hline Yes & 64 & 74.4 \\
No & 22 & 25.6 \\
Total & $\mathbf{8 6}$ & $\mathbf{1 0 0 . 0}$ \\
\hline
\end{tabular}

Table 15 shows that among the respondents who did not get the report of the army "deadly vaccine" from social media, $74.4 \%$ eventually got it from there, while $25.6 \%$ did not. So, ultimately, majority of the respondents read the report on social media platforms.

Table 16 Respondents' Point of Belief of the Army "Deadly Vaccine" Report (For Respondents that Did Not Get the Report First From Social Media)

\begin{tabular}{|c|c|c|}
\hline & Frequency & Percent \\
\hline When I got the news first & 47 & 54.6 \\
\hline When I eventually saw it on social media & 14 & 16.3 \\
\hline At no time & 25 & 29.1 \\
\hline Total & 86 & 100.0 \\
\hline
\end{tabular}

Table 16 shows that among the respondents who did not get the report of the army "deadly vaccine" first from social media, $54.6 \%$ believed it when they got the news first, $16.3 \%$ believed it when they eventually saw it on social media, while $29.1 \%$ believed it at no time. Thus, more than half of the number that got the report first from non-social media source did not have to wait till they saw it on social media to believe it.

Table 17 Respondents' Belief of the Army "Deadly Vaccine" if Social Media Was the Only Source (For Respondents that Got the Report First From Social Media)

\begin{tabular}{|l|l|l|}
\hline & Frequency & Percent \\
\hline Yes & 186 & 75.6 \\
No & 6 & 2.4 \\
Can't tell & 54 & 22 \\
Total & $\mathbf{2 4 6}$ & $\mathbf{1 0 0 . 0}$ \\
\hline
\end{tabular}

Table 17 shows that among the respondents that got the report of the army "deadly vaccine" first from social media, $75.6 \%$ had social media as the only source of the report, meaning that they did not get it from any second source. However, $2.4 \%$ also got it from other sources, but $22 \%$ cannot tell.

Reaction to Report on Army "Deadly Vaccine" 
NNAMDI AZIKIWE UNIVERSITY JOU

Volume 2 Number 1 Jan-Mar Issue

Journal OF COMMUNICATION AND MEDIN STUDIES

DOI: http://dx.doi.org/10.47851/naujocommed.v2i1.121

Table 18 Respondents' Reaction on First Getting the "Deadly Vaccine" Report

\begin{tabular}{|l|l|l|}
\hline & Frequency & Percent \\
\hline I got my wards out of school & 120 & 36.1 \\
I alerted others & 164 & 49.4 \\
I did nothing & 48 & 14.5 \\
Total & $\mathbf{3 3 2}$ & $\mathbf{1 0 0 . 0}$ \\
\hline
\end{tabular}

Table 18 shows that on first getting the "deadly vaccine" report, $36.1 \%$ of the respondents got their wards out of school, $49.4 \%$ alerted others, while $14.5 \%$ did nothing. Thus, almost half of the respondents alerted others once they go the report. Only a minority did nothing.

Table 19 Respondents' Reason for Reacting to the "Deadly Vaccine" Report (For the Respondents that Acted)

\begin{tabular}{|l|l|l|}
\hline & Frequency & Percent \\
\hline I acted because I believed the story & 261 & 91.9 \\
I doubted the story but acted out of caution & 23 & 8.1 \\
Total & $\mathbf{2 8 4}$ & $\mathbf{1 0 0 . 0}$ \\
\hline
\end{tabular}

Table 19 shows that for the respondents that acted upon getting the report of the army "deadly vaccine", $91.9 \%$ acted because they believed the report while $8.1 \%$ doubted the story but acted merely out of caution. Thus, majority of those acted did so because they believed the report.

Table 20 Respondents' Reason for Not Reacting to the "Deadly Vaccine" Report (For the Respondents that Did Not Act)

\begin{tabular}{|l|l|l|}
\hline & Frequency & Percent \\
\hline I didn't act because I doubted the story & 42 & 87.5 \\
I believed the story but felt no need to act & 4 & 8.3 \\
No Answer & 2 & 4.2 \\
Total & $\mathbf{4 8}$ & $\mathbf{1 0 0 . 0}$ \\
\hline
\end{tabular}

Table 20 shows that for the respondents that did not act upon getting the report of the army "deadly vaccine", $87.5 \%$ did so because they doubted the story, $8.3 \%$ believed the story but felt no need to act, while $4.2 \%$ gave no answer. Thus, most of the respondents who did not act did so because they doubted the story.

Table 21 Zero Order Correlation of Demographic Variables with Believability and Reaction to the Army "Deadly Vaccine" Report

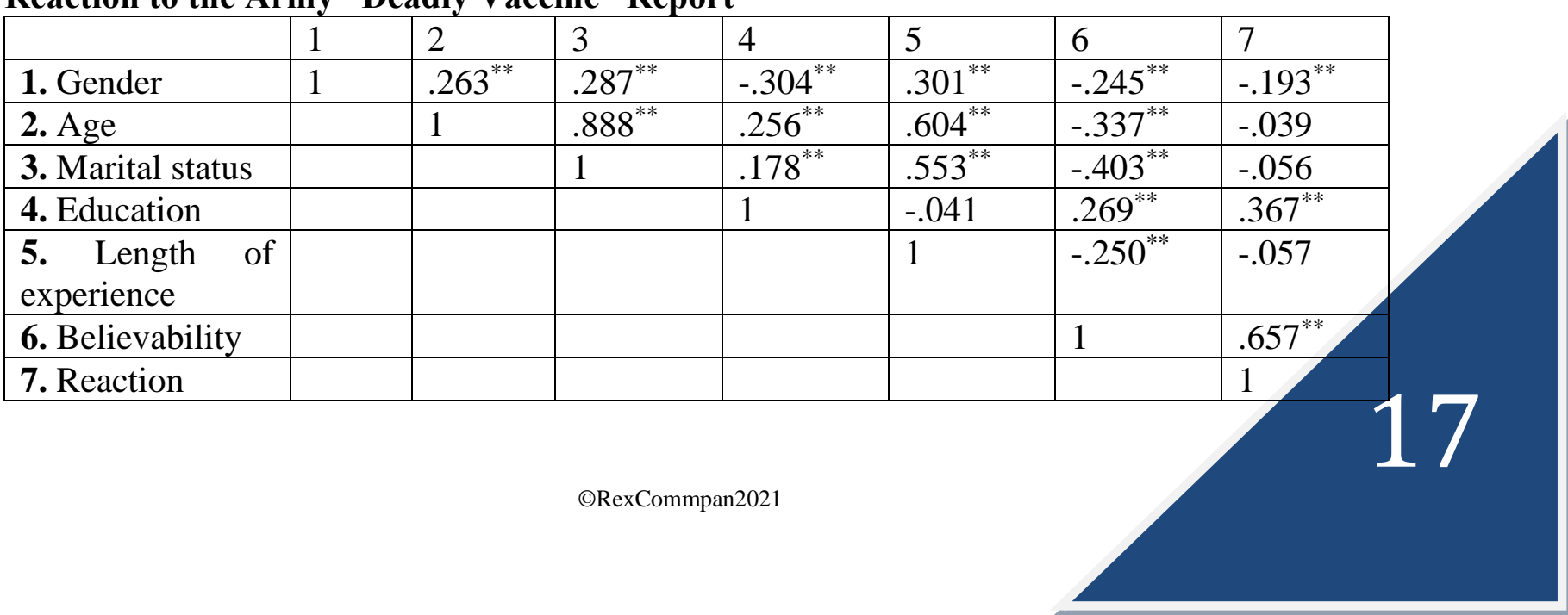


Table 21 shows that gender correlates positively with age $(\mathrm{r}=.263)$, marital status $(\mathrm{r}=.287)$, negatively with education $(r=-.304)$, positively with length of experience $(r=.301)$ and negatively with believability $(r=-.245)$ and reaction $(r=-.193)$. Age correlated positively with marital status $(r=.888)$, education $(r=.256)$, length of experience $(r=.604)$ and negatively with believability $(\mathrm{r}=-.337)$ and reaction $(\mathrm{r}=-.039)$. Education correlates negatively with length of experience $(r=-.041)$ and positively with believability $(r=.269)$ and reaction $(\mathrm{r}=.367)$. Length of experience correlates negatively with believability $(\mathrm{r}=-$ $.250)$ and reaction $(\mathrm{r}=-.057)$, while believability correlates positively with reaction $(\mathrm{r}=$ $.657)$.

\section{ANALYSIS OF RESEARCH QUESTIONS}

The first research question sought to measure the proportion of civil servants in Anambra State that was exposed to the social media posts on the alleged forceful injection of monkey pox virus in schoolchildren. Data in Table 7 shows that $100 \%$ of the respondents were exposed to the message. Furthermore, figures in Table 8 indicate that $85.5 \%$ were exposed to the report via the social media. Similarly, Table 9 shows that majority were exposed to the report via WhatsApp. Consequently, it could be admitted that majority of the civil servants in Anambra State were exposed to the social media posts on the alleged forceful injection of monkey pox virus in schoolchildren and that WhatsApp was the major platform of this exposure.

The second research question sought to assess the proportion of the civil servants in Anambra State that believed the social media posts on the alleged forceful injection of monkey pox virus in schoolchildren. Data in Table 11 indicate that $79.5 \%$ of the respondents believed the report - either completely or with some reservations. Table 12 shows that $41 \%$ never suspected the veracity of the report due to its social media source, while almost $50 \%$ did not see the need to verify the report from a non-social media source. Also, $75.6 \%$ of the respondents who social media was their first source of exposure to the report believed it. Consequently, it could be stated that majority of the civil servants in Anambra State believed the alleged forceful injection of monkey pox virus in schoolchildren.

The third research question sought to find out the proportion of the civil servants that acted in line with the claims made in the posts on the alleged forceful injection of monkey pox virus in schoolchildren. Data in Table 18 indicate that on first getting the "deadly vaccine" report, the major reactions by the respondents were getting their wards from school $(36.1 \%)$ and alerting others (49.4\%). Table 19 indicates that for the respondents that reacted to the post, almost all (91.9\%) acted because they believed the report while just a few (8.1\%) doubted the story but acted merely out of caution. In the same vein, figures in Table 20 show that majority of the respondents that did not react $(87.5 \%)$ did so because they doubted the story. Based on the foregoing, it could be affirmed in answer to the fourth research question that majority of the civil servants reacted to the posts on the alleged forceful injection of monkey pox virus in schoolchildren by bringing their wards back from school and by alerting others of the perceived development.

The fourth research question sought to discover the demographic variables that influenced believability of the social media posts on the alleged forceful injection of monkey pox virus in schoolchildren. The correlation data in Table 21 show that gender, age and length of civil service experience correlates negatively with believability; while education correlate 
DOI: http://dx.doi.org/10.47851/naujocommed.v2i1.121

positively with it. Consequently, it could be stated that gender, age, education and length of civil service experience influenced believability on the October 112017 social media posts on the alleged forceful injection of monkey pox virus in schoolchildren.

The fifth research question sought to discover the demographic variables that influenced response to the social media posts on the alleged forceful injection of monkey pox virus in schoolchildren. The data in table 21 shows that gender, age and length of civil service experience correlate negatively with reaction: while education correlates positively with it. Consequently, it could be stated that gender, age, education and length of service experience influenced response to the social media posts on the alleged forceful injection of monkey pox virus in schoolchildren among civil servants in Anambra State.

\section{DISCUSSION OF FINDINGS}

The first finding of this study which indicated that the majority of the civil servants in Anambra State was exposed to the social media posts on the alleged forceful injection of monkeypox virus in school children, could be said to represent yet another piece of evidence as to the growing influence of social media as a communication platform in the country. This is a global trend (Bryer \& Zavattaro, 2011) as it is a local culture in Nigeria (Okoye, 2011; Nwosu, 2012). Recent statistics on web access and usage (Internet World Stats, 2017) as well as studies (Nababa, 2016; Adeyanju, 2015; Ugwuanyi, 2017; Olley \& Chile, 2015) agree substantially with the findings made herein to the effect that social media could wield as much influence as witnessed with the October 11, 2017, episode when it became the leading channel through which the rumor went viral.

Secondly, the first finding of the study equally indicated that WhatsApp was the primary online platform through which the respondents got exposed to the "deadly vaccine" rumor, which concurs with the position in studies by Nababa (2016) and Ugwuanyi (2017) indicating that WhatsApp has continued to grow into a leading social media platform. The second finding also appeared to reinforce the thesis that online media (and social media in particular) have become significantly influential, it showed that majority of the civil servants believed the social media posts on the alleged forceful injection of monkeypox virus in school children. This is why they reacted to it mainly by bringing their wards back from school and alerting others of the perceived danger. Earlier studies by Adeyanju (2015) and Ugwuanyi (2017) had indicated that the audience, despite having some misgiving about the reliability of social media news, still relied on it for news and indeed believed the news they received from the platforms.

Similarly, Nababa (2016), in his study of the Ebola salt-and-water-therapy hoax circulated via the social media in 2014, found that the audience mostly believed social media-borne rumor. The preceding results essentially agree with the findings made in the present study. The last two findings, indicated that gender, age, education, and length of civil service experience influenced believability and response to the October 11, 2017, social media posts on the alleged forceful injection of monkeypox virus in school children, underscore the role of individual characteristics in their response to the media. It has been a long-upheld paradigm in media effect studies that audiences' demographics constitute a significant determinant of media effect (Daramola, 2003; Baran, 2010; McQuail, 2010). Adeyanju (2015) found that gender, age, and education in+uence response to social media news by the audience, while Ugwuanyi (2017) also found that, occupation also plays a role. Such demographic variable 
DOI: http://dx.doi.org/10.47851/naujocommed.v2i1.121

plays essential roles to audience members perceive a medium (source) as being credible or not. Thus, from the perspective of the source credibility theory, audience members' demographic variations could also have reflected in the extent they trusted and believed the October 11, 2017, social media posts alleging forceful injection of monkeypox virus in schoolchildren. The third and fourth findings of the study tend to support this position.

\section{CONCLUSION}

Based on the preceding, it could be concluded that social media have become quite influential as a source of information and public opinion molder among users in Nigeria. In other words, it has become a significant channel of communication with widespread appeal and credibility such that it could command considerable reaction in the public sphere. Viewed against the backdrop of source credibility theory, study's findings give evidence that social media was positively perceived among the civil servants in Anambra State as having the credibility to supply factual and reliable information. Therefore, with this sort of perception, users are likely to rely considerably on social media platforms for information and opinion formation, which means that they remain susceptible to their possible misleading effects.

\section{RECOMMENDATIONS}

Based on the findings of this research, the following recommendations were made: There should be a continous campaign educating the people on the risk of indiscriminate reliance on social media for information. Such education is aimed at informing the people on better ways of using social media information by verification and other actions. This will help avert potential disasters, which possibly has demonstrated by the Army "deadly vaccine" misinformation.

Government institutions should strengthen their online presence through rigorous utilisation of the internet for conveying vital public information and for countering any misinformation that may arise most time. This way, the vulnerability of the public to social media-based misinformation could be reduced.

Individuals, parents, and young social media content users should be more media literate. Media literacy will enable them to understand the rudiments of media operations and the need not to believe everything they hear, see or read in the media.

\section{REFERENCES}

Abdulla, R. A., Garrison, B., Salwen, M., Driscoll, P. \& Casey, D. (2002). The credibility of newspapers, television news, and online news. A paper presented to the Mass Communication and Society Division, Association for Education in Journalism and Mass Communication, an annual convention, Miami Beach, Fla., August 9, 2002.

Adeyanju, A. (2015). Comparative study of social media, television, and newspapers' news credibility. International Conference on Communication, Media, Technology and Design, 2(1), $69-77$.

Adaja, T. A. \& Ayodele , F. A. (2013). Nigerian youths and social media: Harnessing the potentials for academic excellence. Kuwait Chapter of Arabian 
Volume 2 Number 1 Jan-Mar Issue

DOI: http://dx.doi.org/10.47851/naujocommed.v2i1.121

Journal of Business and Management 2(5), $65-75$.

Akindehin, M. \& Akindehin F. (2011). Online social networking practices of some Nigerian university undergraduates: Implications for counseling. British Journal of Arts and Social Sciences 3(1), $68-78$.

Akinlade, A. A. (2017). Social media in+uence on the voting behaviur of the youth in South east Nigeria (Master's thesis). University of Nigeria, Nsukka.

Retrieved from http://repository.unn.edu.ng:8080/xmlui/bitstream/handle/123456789/4323/A kinlade $\% 2 \mathrm{C} \% 20 \mathrm{Ajibola} \% 20 \mathrm{~A}$..pdf? sequence $=1$

Akuezuilo, and Agu, N. (2002). Research and statistics in education and social sciences. (Millenium Edition). Awka: Nuel and Cent Publishers.

Alawode, S. O. \& Adesanya, O. O. (2016). Content analysis of 2015 political election advertisements in selected national dailies of Nigeria. European

Scienti*c Journal, 12(5), $234-259$.

Baran, S. J. (2010). Introduction to mass communication, media literacy, and culture $\left(6^{\text {th }}\right.$ ed.). New York: McGraw-Hill.

Bonds-Raacke,J., \& Raacke, J. (2010). Myspace and Facebook: Identifying dimensions of uses and grati*cations for friend networking sites. Individual Differences Research, 8(1), 27-33.

Bryer, T.A. \& Zavattaro, S.M. (2011). Social media and public administration: Theoretical dimensions and introduction to the symposium. Administrative Theory \& Praxis, 33(3), 325-340.

Chinedu-Okeke, C. F. \& Obi, I. (2016). Social media as a political platform In Nigeria: A focus on electorates in South-Eastern Nigeria. IOSR Journal of Humanities And Social Science (IOSR-JHSS), 21(11), 06 - 22.

Chukwunweike, B. N. (2017). Social media and health posts: An assessment of audience response on epidemics (Unpublished master's thesis). Nnamdi Azikiwe University, Awka.

Daramola, I. (2003). Introduction to mass communication (2nd ed.). Lagos: Rothan Press.

Emetumah, F. I. (2016). Social media as a factor for increased frontiers of democracy in Nigeria's 2015 presidential election. British Journal of Education, Society \& Behavioural Science, 17(4), 1 - 9.

Erdogan, B. (1999). Celebrity endorsement: A literature review. Journal of Marketing Management, 15 (4), 291-314.

Graziano, C. \& McGrath, K. (1986). Measuring the concept of credibility. Journalism Quarterly, 63, 451-462. 
Hilligoss, B. \& Rieh, S. Y. (2008). Developing a unifying framework of credibility assessment: Construct, heuristics, and interaction in context. Information Processing and Management, 44(4), 1467-1484.

Hernon, P. (1995). Disinformation and misinformation through the Internet: Findings of an exploratory study. Government Information Quarterly, 12, 133139.

Hovland, C., \& Weiss, W. (1951). The in+uence of source credibility on communication effectiveness. Public Opinion Quarterly, 15(4), 635 - 650. Internet World Stats (2017). Internet users in Africa 2017. Retrieved from http://www.internetworldstats.com/stats1.htm

Kaplan, A.M. and Haenlein, M. (2010). Users of the world, Unite! The challenges and opportunities of social media. Business Horizons, 53, 59-68. http://michaelhaenlein.com/publications/kaplan,\%20Andreas\%20$\% 20$ Users $\% 20$ of\%20the\%20world\%20unite.pdf

Kaufman, D., Stasson, M. \& Hart, J. (1999). Are the tabloids always wrong, or is that just what we think? Need for cognition and perceptions of articles in print media. Journal of Applied Social Psychology, 29, 1984-1997.

Kiousis, S. (2001). Public trust or mistrust? Perceptions of media credibility in the information age. Mass Communication Society, 4, 381-403.

McQuail, D. (2010). McQuail's mass communication theory (5th ed.) London: Sage.

Metzger, M.J., Flanagin, A.J., Eyal,K. Lemus, D.R., \& Mccann, R.M. (2003). Credibility for the 21st Century: Integrating perspectives on source, message, and media credibility in the contemporary media environment. Communication Yearbook, 27, 293-336

Nababa, G. S. (2016). Information credibility on social networking sites: a study of a salt-and-warm-water anti-Ebola prank in Nigeria. Paper presented at the 3rd International Conference on Environmental and Economic Impact on Sustainable Development (EID 2016).

Nwosu, J. O. (2012). SMS as a platform for social discussion during the national minimum debate of 2012. Retrieved from http://mediaarena.com/acdemic_papers/nwosu_social-media.

Obukoadata, P. O. \& Abuah, F. A. (2014). Media surveillance function within the context of the Ebola outbreak in Nigeria: In+uences and perceptual frames. International Journal of Scienti*c Research and Innovative Technology, 1(5), 53 $-66$

Ohanian, R. (1991). The impact of celebrity spokespersons' perceived image on consumer intention to purchase. Journal of Advertising Research, 2, 46 - 54. 
NNAMDI AZIKIWE UNIVERSITY Journal OF COMMUNICATION AND MEDIA STUDIES

Volume 2 Number 1 Jan-Mar Issue

DOI: $\underline{\text { http://dx.doi.org/10.47851/naujocommed.v2i1.121 }}$

Okachie, L. (2017, October 15). Python Dance II: The inside story of the Monkeypox vaccine rumor. Daily Trust, pp.13 - 14 .

Okoye, J. S. (2011). Online newspaper readers' response to feedback invitation: A survey of regular readers of The Punch, The Sun, The Guardian and Daily Trust. UNILAG Journal of Communication, 3(5), 1 - 21. 